\title{
Chitosan inserts for periodontitis: Influence of drug loading, plasticizer and crosslinking on in vitro metronidazole release
}

\author{
ROMI BARAT ${ }^{1}$ \\ ANEGUNDHA SRINATHA ${ }^{1}$ \\ JAYANTA K. PANDIT ${ }^{1 *}$ \\ SHAMPA ANUPURBA ${ }^{2}$ \\ NEELAM MITTAL ${ }^{3}$ \\ 1 Department of Pharmaceutics \\ Institute of Technology \\ Banaras Hindu University \\ Varanasi-221005, India \\ 2 Department of Microbiology \\ Institute of Medical Sciences \\ Banaras Hindu University \\ Varanasi-221005, India \\ ${ }^{3}$ Faculty of Dental Sciences \\ Institute of Medical Sciences \\ Banaras Hindu University \\ Varanasi-221005, India
}

\begin{abstract}
Chitosan based metronidazole (MZ) inserts were fabricated by the casting method and characterized with respect to mass and thickness uniformity, metronidazole loading and in vitro metronidazole release kinetics. The fabricated inserts exhibited satisfactory physical characteristics. The mass of inserts was in the range of $5.63 \pm 0.42$ to $6.04 \pm 0.89 \mathrm{mg}$. The thickness ranged from $0.46 \pm 0.06$ to $0.49 \pm 0.08 \mathrm{~mm}$. Metronidazole loading was in the range of $0.98 \pm 0.09$ to $1.07 \pm 0.07 \mathrm{mg}$ except for batch CM3 with MZ loading of $2.01 \pm 0.08 \mathrm{mg}$. The inserts exhibited an initial burst release at the end of $24 \mathrm{~h}$, irrespective of the drug to polymer ratio, plasticizer content or cross-linking. However, further drug release was sustained over the next 6 days. Cross-linking with $10 \%(\mathrm{~m} / \mathrm{m})$ of glutaraldehyde inhibited the burst release by $\sim 30 \%$ and increased the mean dissolution time (MDT) from 0.67 to 8.59 days. The decrease in drug release was a result of reduced permeability of chitosan due to cross-linking.
\end{abstract}

Keywords: chitosan inserts, cross-linking, metronidazole, periodontitis, sustained release

Accepted September 10, 2007

Periodontitis, a disease involving supportive structures of the teeth prevails in all groups, ethnicities, races and both genders. The relationship between bacterial plaque and the development of periodontal disease and caries is well established (1). Antibacterial agents have been used effectively in the management of periodontal infection. The effectiveness of mechanical debridement of plaque and repeated topical and systemic administration of antibacterial agents are limited due to the lack of accessibility to periodontopathic organisms in the periodontal pocket (2). Systemic administration of drugs leads to therapeutic concentrations at the site of infection, but for short periods of time, forcing repeated dosing for longer periods (3). Local delivery of antimicrobials has been investigated for the possibility of overcoming the limitations of conventional therapy. The use of sustained release formulations to deliver antibacterials to the site of infection

\footnotetext{
* Correspondence, e-mail: jkpandit@gmail.com
} 
R. Barat et al.: Chitosan inserts for periodontitis: Influence of drug loading, plasticizer and crosslinking on in vitro metronidazole release, Acta Pharm. 57 (2007) 469-477.

(periodontal pocket) has recently gained interest. These products provide a long-term, effective treatment at the site of infection at much smaller doses (4). Biodegradable polymers are extensively employed in periodontal drug delivery devices because of their abundant source, lack of toxicity, and high tissue compatibility (5). A major advantage of natural polymers is that they do not affect periodontal tissue regeneration. Amongst various natural polymers, chitosan, a deacetylated product of chitin is widely used in drug delivery devices. Since it exhibits favourable biological properties such as non-toxicity, biocompatibility (6), biodegradability and wound healing traits (7), it has attracted great attention in the pharmaceutical and biomedical fields.

Metronidazole (MZ), a nitroimidazole derivative, is effective against periodontal pathogens (8-10). It is the drug of choice in the case of pathogenic Gram negative anaerobes. Systemic metronidazole has been employed in the control of chronic periodontal diseases $(11,12)$. Topical metronidazole therapy has been used as an alternative (13) and as an adjunct to scaling and root planning (14). Dental gels containing metronidazole $(25 \%, m / V)$ in glyceryl monooleate have been studied (15-17). The present study is aimed at developing chitosan biodegradable inserts of metronidazole for local long-term treatment of periodontal disease. The fabricated inserts were evaluated for their physical properties and in vitro drug release characteristics.

\section{EXPERIMENTAL}

\section{Materials}

Metronidazole was obtained as a gift sample from M/s Ranbaxy Laboratories (India). Chitosan (viscosity 0.05 Pa s), was generously donated by Cochin Fisheries Ltd (India). All other reagents used were of analytical grade.

\section{Methods}

Preparation of inserts. - Drug loaded and placebo inserts were prepared by the method described by Oungbho and Muller (18), with modification. A homogeneous gel-like solution of chitosan was prepared by dispersing weighed amount of chitosan in $2 \%$ $(V / V)$ acetic acid under constant stirring. Metronidazole was passed through a $53-\mu \mathrm{m}$ sieve and dispersed in $1 \%(V / V)$ acetic acid solution. Drug dispersion was mixed with chitosan solution for $6 \mathrm{~h}$. A measured amount of cross-linking agent (glutaraldehyde/ formaldehyde) was added to the solution and stirred for $6 \mathrm{~h}$. Plasticizer (propylene glycol, PG) was then added to the drug-polymer mixture (Table I). After deaerating under vacuum for $6 \mathrm{~h}$, the drug-polymer mixture was poured on leveled glass moulds at $50{ }^{\circ} \mathrm{C}$ and dried for 10-12 h. The films were subdivided into inserts $(2 \times 6 \mathrm{~mm})$ by punching out. Dried films were wrapped in butter paper and stored in amber colored glass vials in a desiccator until further use.

Physical properties of inserts. - The fabricated inserts were evaluated for thickness, mass and drug content uniformity (19). Drug content uniformity, between batches and within batches, was determined by dissolving individually weighed inserts $(n=6)$ in $5 \mathrm{~mL}$ 
R. Barat et al: Chitosan inserts for periodontitis: Influence of drug loading, plasticizer and crosslinking on in vitro metronidazole release, Acta Pharm. 57 (2007) 469-477.

Table I. Composition of the fabricated metronidazole inserts by casting method in $2 \%(\mathrm{~V} / \mathrm{V})$ glacial acetic acid

\begin{tabular}{ccccc}
\hline Batch code & $\begin{array}{c}\text { Chitosan } \\
\left(\mathrm{mg} \mathrm{cm}^{-2}\right)\end{array}$ & $\begin{array}{c}\text { Metronidazole } \\
(\text { mg per insert })\end{array}$ & $\begin{array}{c}\text { Plasticizer PG } \\
(\%, \mathrm{~m} / \mathrm{m})\end{array}$ & $\begin{array}{c}\text { Cross-linking agent } \\
(\%, \mathrm{~m} / \mathrm{m})\end{array}$ \\
\hline CM1 & 40 & 1 & 10 & - \\
CM2 & 40 & 1 & 40 & - \\
CM3 & 40 & 2 & 10 & - \\
CM4 & 40 & 1 & 40 & 5 (HCHO) \\
CM5 & 40 & 1 & 40 & 5 (glutaraldehyde) \\
CM6 & 40 & 1 & 40 & 10 (glutaraldehyde) \\
CM7 & 40 & 1 & 40 & \\
\hline
\end{tabular}

PG - propylene glycol

of glacial acetic acid in a volumetric flask. After gentle swirling for an hour, the volume was made up to $100 \mathrm{~mL}$ with Mcllvaine's buffer $\mathrm{pH} 6.6$ (potassium dihydrogen orthophosphate and citric acid in water). The final $\mathrm{pH}$ of the buffer solution was adjusted using either $1 \mathrm{~mol} \mathrm{~L}^{-1}$ potassium dihydrogen orthophosphate solution or $0.5 \mathrm{~mol} \mathrm{~L}^{-1}$ citric acid solution, as required. The resultant solution was filtered through a G-2 glass filter $(40 \mu \mathrm{m})$. An aliquot of the filtrate was suitably diluted and analyzed for metronidazole content at $316 \mathrm{~nm}$ on a UV spectrophotometer (UV-1601, Shimadzu, Japan). The thickness of the inserts was measured at 5 different randomly selected spots with a screw gauge. For mass uniformity, 10 inserts from each batch were weighed individually and their average was determined.

In vitro release studies. - Weighed inserts were placed in a stainless steel wire mesh $(250 \mu \mathrm{m})$ holder of dimensions $4 \times 8 \mathrm{~mm}$ and suspended in amber colored vials containing $10 \mathrm{~mL}$ of McIlvaine's buffer $\mathrm{pH} 6.6$ (to simulate $\mathrm{pH}$ of gingival crevicular fluid in vitro) as the dissolution medium. The vials were stoppered and placed on a vial holder fitted in a water bath thermostated at $37 \pm 1{ }^{\circ} \mathrm{C}$. At pre-determined time intervals, the dissolution medium was completely withdrawn and replaced with a fresh $10 \mathrm{~mL}$ portion of pre-warmed buffer, which ensured sink conditions. Since the formulations provide a high initial burst release of metronidazole, during the first $24 \mathrm{~h}$ drug release study, samples were collected every hour to maintain sink conditions. Metronidazole released was determined at $316 \mathrm{~nm}$ after suitable dilution. A dissolution study of film devoid of metronidazole was performed concurrently to nullify any interference by film materials.

Drug release kinetics. - The drug release kinetics from the fabricated inserts was evaluated using Higuchi's equation: $Q=k t^{1 / 2}(20)$, where $Q$ is the amount of drug released, $k$ is the release constant and $t$ is time. Further, the data was fitted to Korsmeyer-Peppas' power law equation: $M_{t} / M_{\infty}=K t^{n}(21)$, where, $M_{t} / M_{\infty}$ is the fraction of drug released in time $t, K$ is the structural and geometric constant, and $n$ is the release exponent.

Statistical evaluation. - The in vitro data were analyzed for statistical significance using Student's $t$-test. 
R. Barat et al:: Chitosan inserts for periodontitis: Influence of drug loading, plasticizer and crosslinking on in vitro metronidazole release, Acta Pharm. 57 (2007) 469-477.

\section{RESULTS AND DISCUSSION}

The inserts were prepared by the casting method with controlled solvent evaporation. However, incorporation of plasticizer (propylene glycol) was necessary to obtain films with sufficient flexibility and allow subsequent sub-division into inserts. The plasticizer concentration was optimized to $40 \%(\mathrm{~V} / \mathrm{V})$. Although a lower level of propylene glycol could have been used, on drying harder inserts with little or no flexibility were obtained. The formulated inserts were evaluated for various physico-chemical properties and the results are given in Table II. The mass and thickness of the prepared inserts was in the range of $5.63 \pm 0.42$ to $6.04 \pm 0.89 \mathrm{mg}$ and $0.46 \pm 0.06$ to $0.49 \pm 0.08 \mathrm{~mm}$, respectively. The drug content was found to be in the range of $0.98 \pm 0.09$ to $1.07 \pm 0.07 \mathrm{mg}$ except for batch CM3 with $2.01 \pm 0.08 \mathrm{mg}$ MZ.

Table II. Physico-chemical characterization and release rate constants of fabricated insert

\begin{tabular}{cccccc}
\hline Batch code & $\begin{array}{c}\text { Mass } \\
(\mathrm{mg})^{\mathrm{a}}\end{array}$ & $\begin{array}{c}\text { Thickness } \\
(\mathrm{mm})^{\mathrm{a}}\end{array}$ & $\begin{array}{c}\text { Drug content } \\
(\mathrm{mg})^{\mathrm{a}}\end{array}$ & $\begin{array}{c}k \\
\left(\mathrm{\mu g} \mathrm{h}^{-1 / 2} \mathrm{~cm}^{-2}\right)\end{array}$ & $R$ \\
\hline CM1 & $5.63 \pm 0.42$ & $0.48 \pm 0.07$ & $0.98 \pm 0.09$ & 0.78 & 0.9783 \\
CM2 & $5.94 \pm 0.53$ & $0.49 \pm 0.08$ & $1.06 \pm 0.06$ & 0.91 & 0.9281 \\
CM3 & $5.97 \pm 0.89$ & $0.47 \pm 0.07$ & $2.01 \pm 0.08$ & 0.95 & 0.8131 \\
CM4 & $5.86 \pm 0.87$ & $0.46 \pm 0.06$ & $0.99 \pm 0.03$ & 0.85 & 0.9917 \\
CM5 & $6.01 \pm 0.87$ & $0.47 \pm 0.07$ & $1.02 \pm 0.08$ & 0.80 & 0.9882 \\
CM6 & $6.04 \pm 0.89$ & $0.46 \pm 0.09$ & $1.07 \pm 0.07$ & 0.92 & 0.9627 \\
CM7 & $5.98 \pm 0.91$ & $0.48 \pm 0.07$ & $1.05 \pm 0.07$ & 0.98 & 0.9738 \\
\hline
\end{tabular}

a Mean $\pm \mathrm{SD}, n=3$.

Drug release studies were performed by a static method. The inserts released the drug in a biphasic manner with an initial burst release followed by slow release for the next 7 days. The lowest burst release of $68 \%$ was observed with glutaraldehyde $(10 \%$, $\mathrm{m} / \mathrm{V}$ ) crosslinked inserts batch CM7 (1 mg MZ, PG 40\%, $\mathrm{m} / \mathrm{m})$. However, further drug release was sustained for the next 7 days of the release study. The burst effect in the initial stages could be due to the release of drug entrapped on the surface of inserts. Considering the initial pathological load in the periodontal pocket, an initial burst release of anti-microbial is always desirable.

In vitro release studies show that the metronidazole to chitosan ratio plays an important role in the modulation of metronidazole release from the inserts (Fig. 1). Drug release decreased as the chitosan ratio in the inserts increased. The release of metronidazole from batch CM3 (2 mg MZ per insert, PG 10\%, m/m) was at a rate of $39 \mu \mathrm{g} \mathrm{h}^{-1}$ on day 1 in comparison with $33 \mu \mathrm{g} \mathrm{h} \mathrm{h}^{-1}$ from batch CM1 (1 mg MZ per insert, PG 10\%, $\left.\mathrm{m} / \mathrm{m}\right)$. Thus, nearly 94 and $80 \%$ of drug was depleted, respectively, from inserts CM3 and CM1 with no cross-linking agent, in $24 \mathrm{~h}$. The increased release rate from CM3 might partly due to the drug entrapped in the superficial layer of the insert. When the insert comes in contact with dissolution medium, the drug from the surface leaches into the surrounding medium, leaving a more porous polymer structure, which enables faster drug diffusion 
R. Barat et al:: Chitosan inserts for periodontitis: Influence of drug loading, plasticizer and crosslinking on in vitro metronidazole release, Acta Pharm. 57 (2007) 469-477.

Fig. 1. Effect of metronidazole loading on in vitro release rate from inserts at 24 -h time intervals; inset graph represents drug release in the first $24 \mathrm{~h}$ (Mean \pm SD, $n=3$ ).

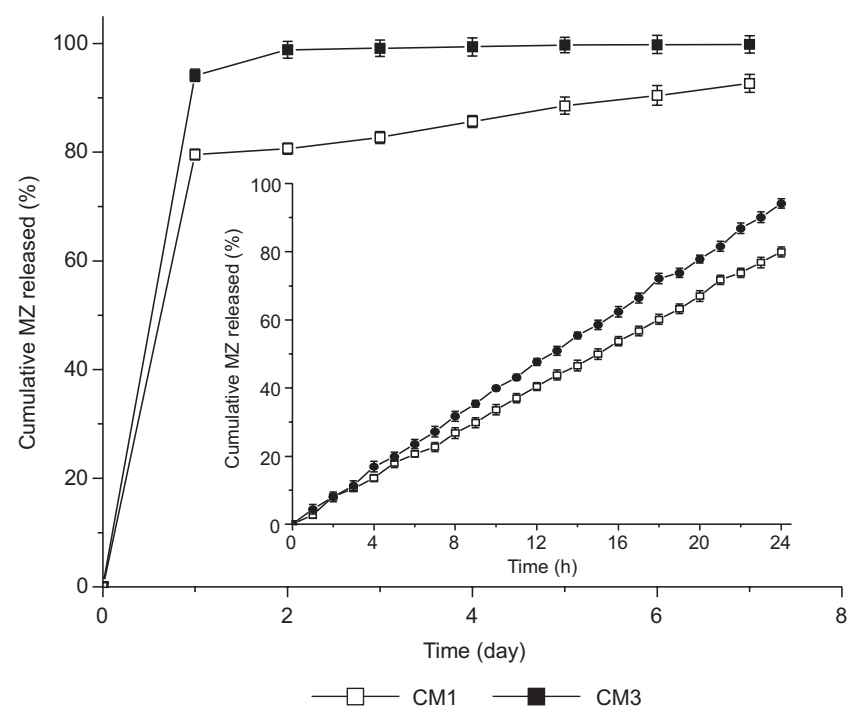

from the matrix. The release rate was found to decrease with increasing the polymer concentration. As shown in Fig. 2, the concentration of propylene glycol in the inserts seems to affect the release rate. It was observed that as the concentration of propylene glycol increased from 10 to $40 \%, \mathrm{~m} / \mathrm{m}$, the rate of metronidazole release increased from $33 \mu \mathrm{g} \mathrm{h}{ }^{-1}$ in CM1 $(10 \%, m / m, \mathrm{PG})$ to $38 \mu \mathrm{g} \mathrm{h}^{-1}$ in CM2 $(40 \%, \mathrm{~m} / \mathrm{m}, \mathrm{PG})$. The change in the observed release rate was possibly due to alteration in membrane permeability caused by the modification of film hydrophilicity by the plasticizer (22).

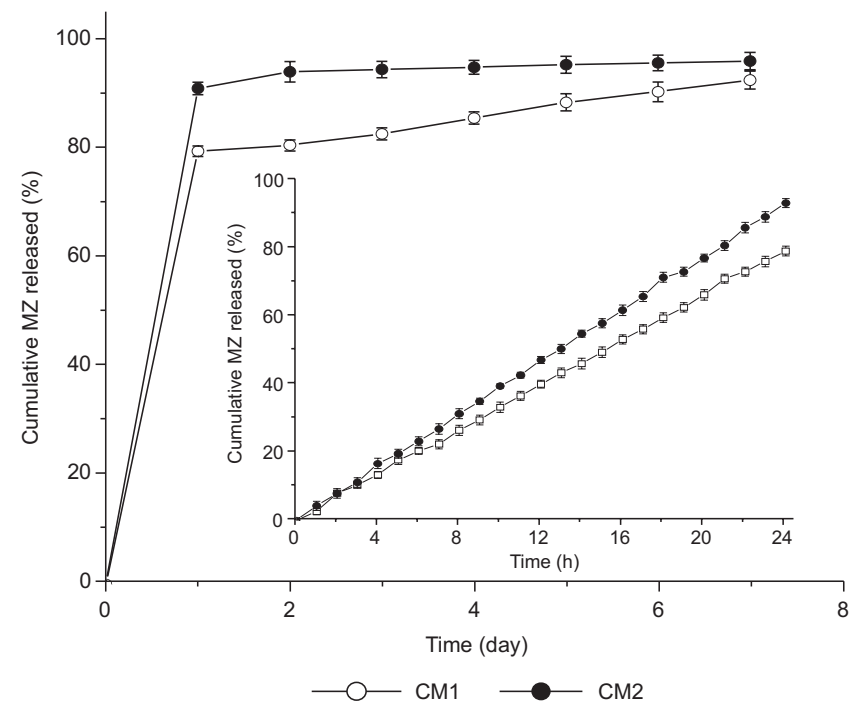

Fig. 2. Effect of plasticizer content on in vitro metronidazole release at 24-h time intervals; inset graph represents drug release in first $24 \mathrm{~h}$ (Mean $\pm \mathrm{SD}$, $n=3)$. 


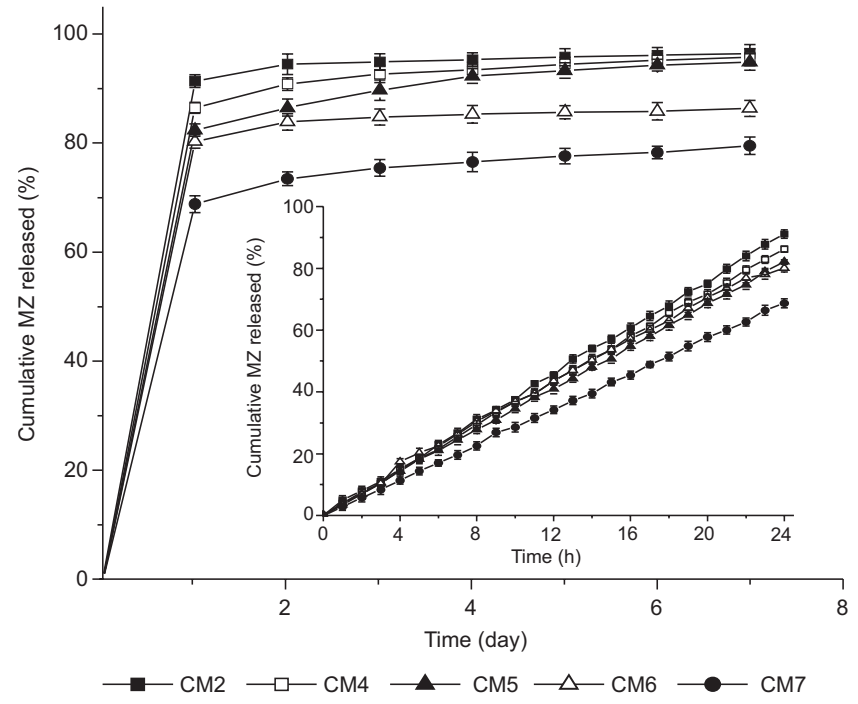

Fig. 3. Effect of cross-linking with formaldehyde and glutaraldehyde on in vitro release rate of metronidazole in comparison to uncross-linked inert; inset graph represents drug release in first $24 \mathrm{~h}$ (Mean $\pm \mathrm{SD}, n=3$ ).

The release rate was affected by the cross-linking of chitosan inserts (Fig. 3). Cross-linking of the inserts with either formaldehyde or glutaraldehyde decreased the drug release rate in comparison with uncross-linked inserts (e.g., CM2, $1 \mathrm{mg} \mathrm{MZ,} \mathrm{PG} \mathrm{40 \% ,} \mathrm{m} / \mathrm{m}$ ). However, even after cross-linking, there was no significant decrease in the burst release. Of the two aldehydes tested, glutaraldehyde as cross-linking agent was more effective in decreasing both the burst release and subsequent release rate. Chitosan-metronidazole insert, cross-linked with $10 \%(\mathrm{~m} / \mathrm{m})$ glutaraldehyde $(\mathrm{CM} 7,1 \mathrm{mg}$ MZ per insert, PG $40 \%$, $\mathrm{m} / \mathrm{m}$ ) had an initial burst release rate of $29 \mu \mathrm{g} \mathrm{h}{ }^{-1}$, which gradually decreased to around $1 \mu \mathrm{g} \mathrm{h}-1$ at the end of $48 \mathrm{~h}$. Further release rate was maintained at $1 \mu \mathrm{g} \mathrm{h}^{-1}$ to the end of day 7. The mean dissolution time (MDT) increased to 6.4 and 8.6 days, respectively, for CM6 and CM7 both containing $1 \mathrm{mg}$ MZ per insert but crosslinked with 5 and $10 \%(\mathrm{~m} / \mathrm{m})$ glutaraldehyde, respectively. This was a significant change since the not cross-linked insert (CM2) exhibited MDT of 0.7 days. This difference in release rate is due to the decrease in the permeability coefficient of the cross-linked membrane resulting from the cross-link points (23). A similar decrease in meloxicam release from cross-linked gelatin inserts has been reported recently (24).

Table II shows the treatment of release data according to the Higuchi equation. The results indicate that the amount of drug released per unit area $(Q)$ increased with the square root of time. Furthermore, the release coefficient $n<0.45$ for all prepared batches, suggests diffusion as the dominant release mechanism, and not a combination of swelling and erosion. The release rate constant $(k)$ was $>0.7$ for all batches. The high release rate constant was a result of the initial burst release exhibited by the inserts. 
R. Barat et al: Chitosan inserts for periodontitis: Influence of drug loading, plasticizer and crosslinking on in vitro metronidazole release, Acta Pharm. 57 (2007) 469-477.

\section{CONCLUSIONS}

The inserts exhibited burst release, which is desirable considering the initial pathogenic load in periodontal pockets, but provided sustained release for subsequent six days. The in vitro evaluation results are encouraging and need further evaluation of the inserts in patients suffering from periodontitis.

Acknowledgements. - The financial assistance of the Department of Science and Technology, Government of India, is gratefully acknowledged.

\section{REFERENCES}

1. P. Axelsson and J. Lindhe, Effect of controlled oral hygiene procedures on caries and periodontal disease in adults, J. Clin. Periodontol. 5 (1978) 133-151; DOI: 10.1111/j.1600-051X.1978.tb01914.x.

2. N. J. Medlicott, I. G. Tucker and D. W. Holborow, Delivery systems for the administration of drugs to the periodontal pocket, Adv. Drug Del. Rev. 13 (1994) 181-203; DOI: 10.1016/0169-409X (94)90033-7.

3. J. Slots and T. E. Rams, Antibiotics in periodontal therapy: advantages and disadvantages, J. Clin. Periodontol. 17 (1990) 479-93.

4. T. S. Kim, T. Burklin, B. Schacher, P. Ratka-Kruger, M. T. Schaecken, H. H. Renggli, W. Fiehn and P. Eickholz, Pharmacokinetic profile of a locally administered doxycycline gel in crevicular fluid, blood, and saliva, J. Periodontol. 73 (2002) 1285-1291; DOI: 10.1902/jop.2002.73.11.1285.

5. K. Schwach-Abdellaoui, N. Vivien-Casioni and R. Gurny, Local delivery of antimicrobial agents for the treatment of periodontal disease, Eur. J. Pharm. Biopharm. 50 (2000) 83-99; DOI: 10.1016/ S0939-6411(00)00086-2.

6. T. Chandy and C. P. Sharma, Chitosan as a biomaterial, Biomaterial Artif. Cells Artif. Organs 18 (1990) 1-24.

7. R. Muzzarelli, V. Baldassarre, F. Conti, P. Ferrara and G. Biagini, Biological activity of chitosan: ultrastructural study, Biomaterials 9 (1988) 247-252; DOI: 10.1016/0142-9612(88)90092-0.

8. J. Lindhe, A. D. Haffajee and S. S. Socransky, Progression of periodontal disease in adult subjects in the absence of periodontal therapy, J. Clin. Periodontol. 10 (1983) 433-442; DOI: 10.1111 / j.1600-051X.1983.tb01292.x.

9. H. N. Newman, F. I. S. Yeung, W. Z. A. B. Wan-Yusof and M. Addy, Slow release metronidazole and a simplified mechanical oral hygiene regimen in the control of chronic periodontitis, J. Clin. Periodontol. 11 (1984) 576-582; DOI: 10.1111/j.1600-051X.1984.tb00910.x.

10. F. A. Gusberti, S. A. Syed and N. P. Long, Combined antibiotic (metronidazole) and mechanical treatment effects on the subgingival bacterial flora of sites with recurrent periodontal disease, J. Clin. Periodontol. 15 (1988) 353-359; DOI: 10.1111/j.1600-051X.1988.tb01011.x.

11. W. J. Loesche, Antibiotic therapy as part of periodontal therapy, Phillip J. 6 (1989) 95-104.

12. M. A. Van-Oosten, F. J. Notten and F. H. Mikx, Metronidazole concentrations in human plasma, saliva, and gingival crevice fluid after a single dose, J. Dental Res. 65 (1986) 1420-1423.

13. V. Pedrazzoli, M. Kilian and T. Karring, Comparative clinical and microbiological effects of topical subgingival application of metronidazole $25 \%$ dental gel and scaling in the treatment of adult periodontitis, J. Clin. Periodontol. 19 (1992) 715-722.

14. C. Hitzig, T. Fosse, Y. Charbit, C. Bitton and L. Hannoun, Effects of combined topical metronidazole and mechanical treatment on the subgingival flora in deep periodontal pockets in cuspids and bicuspids, J. Periodontol. 68 (1997) 613-617. 
R. Barat et al: Chitosan inserts for periodontitis: Influence of drug loading, plasticizer and crosslinking on in vitro metronidazole release, Acta Pharm. 57 (2007) 469-477.

15. K. Stolze, Concentration of metronidazole in periodontal pockets after application of a metronidazole 25\% dental gel, J. Clin. Periodontol. 19 (1992) 698-701.

16. K. Stolze and M. Stellfield, Systemic absorption of metronidazole after application of a metronidazole 25\% dental gel, J. Clin. Periodontol. 19 (1992) 693-697.

17. J. Ainamo, T. Lie, B. H. Ellingsen, B. F. Hansen, L. A. Johansson, T. Karring, J. Kisch, K. Paunio and K. Stolze, Clinical responses to subgingival application of a metronidazole $25 \%$ gel compared to the effect of subgingival scaling in adult periodontitis. J. Clin. Periodontol. 19 (1992) 723-729.

18. K. Oungbho and B. W. Muller, Chitosan sponges as sustained release drug carriers, Int. J. Pharm. 156 (1997) 229-237; DOI: 10.1016/S0378-5173(97)00201-9.

19. R. Barat, A. Srinatha, J. K. Pandit, D. Ridhurkar, J. Balasubramaniam, N. Mittal and D. N. Mishra, Niridazole biodegradable inserts for local long term treatment of periodontits: Possible new life for an orphan drug, Drug Deliv. 13 (2006) 365-373; DOI: 10.1080/10717540500398126.

20. T. Higuchi, Mechanism of sustained action medication, theoretical analysis of rate of solid drug dispersed in solid matrices, J. Pharm. Sci. 52 (1963) 1145-1149; DOI: 10.1002/jps.2600521210.

21. R. W. Korsmeyer, R. Gurny, E. M. Doelker, P. Buri and N. A. Peppas, Mechanism of solute release from porous hydrophilic matrices, Int. J. Pharm.15 (1983) 25-35; DOI: 10.1016/0378-5173 (83)90064-9.

22. Z. J. Shao, L. Morales, S. Diaz and N. A. Muhammad, Drug release from kollicoat SR 30D-coated nonpareil beads: evaluation of coating, plasticizer type, and curing condition, AAPS PharmSciTech. 3 (2002) article 15.

23. D. Thacharodi and K. P. Rao, Development and in vitro evaluation of chitosan-based transdermal drug delivery systems for the controlled release of propranolol hydrochloride, Biomaterials 16 (1995) 145-148; DOI: 10.1016/0142-9612(95)98278-M.

24. E. O. Cetin, N. Buduneli, E. Atlihan and L. Kirilmaz, In vitro studies of a degradable device for controlled release of meloxicam, J. Clin. Periodontol. 32 (2005) 773-777; DOI: 10.1111/j.1600051X.2005.00755.x.

$S A \check{Z} E T A K$

\section{Kitozanski umetci za periodontitis: Utjecaj količine lijeka, plastifikatora i umrežavanja na oslobađanje metronidazola in vitro}

ROMI BARAT, ANEGUNDHA SRINATHA, JAYANTA K. PANDIT, SHEMPA ANUPURBA i NEELAM MITTAL

Umetci metronidazola na bazi kitozana načinjeni su kasting metodom. Proučavana je ujednačenost mase i debljine, količina ljekovite tvari i kinetika oslobađanja metronidazola in vitro. Fizičke karakteristike umetaka bile su zadovoljavajuće: masa je bila u rasponu od 5,63 $\pm 0,42-6,04 \pm 0,89 \mathrm{mg}$, debljina od $0.46 \pm 0.06-0.49 \pm 0.08 \mathrm{~mm}$, količina metronidazola od 0,98 $\pm 0,09-1,07 \pm 0,07 \mathrm{mg}$ osim u pripravku CM3 s MZ 1,07 $\pm 0,07$ mg. Nakon $24 \mathrm{~h}$, neovisno o omjeru ljekovite tvari i polimera, količini plastifikatora ili umrežavanju, dio metronidazola se naglo oslobodio iz svih umetaka. Međutim, daljnje je oslobađanje bilo polagano, tijekom 6 dana. Umrežavanje s 10\% ( $\mathrm{m} / \mathrm{m})$ otopinom glutaraldehida spriječilo je naglo oslobađanje za $\sim 30 \%$ i povećalo srednje vrijeme oslobađanja (MDT) s 0,67 na 8,59 dana. Smanjenje u oslobađanju ljekovite tvari posljedica je smanjenja permeabilnosti umreženog kitozana. 
R. Barat et al: Chitosan inserts for periodontitis: Influence of drug loading, plasticizer and crosslinking on in vitro metronidazole release, Acta Pharm. 57 (2007) 469-477.

Ključne riječi: kitozanski umetci, umrežavanje, metronidazol, periodontitis, polagano oslobađanje Department of Pharmaceutics, Institute of Technology, Banaras Hindu University, Varanasi-221005, India Department of Microbiology, Institute of Medical Sciences, Banaras Hindu University, Varanasi-221005, India Faculty of Dental Sciences, Institute of Medical Sciences, Banaras Hindu University, Varanasi-221005, India 